CIHM Microfiche Series (Monographs)
ICMH

Collection de microfiches (monographies)

$T$ $\mathrm{cc}$ $m$ in ct 


\section{Technical and Bibliographic Notes / Notes techniques et bibliographiques}

The Institule has attempled to oblain the best original copy available for filming. Features of this copy which may be bibliographically unique, which may alter any of the images in the reproduction, or which may significantly change the usual method of filming are checked below.

Coloured covers I

Couverture de couleur

Covers damaged /

Couverture endommagée

Covers reslored and/or laminated/

Couverture restaurée eVou pelliculée

Cover title missing / Le titre de couverture manque

Coloured maps / Cartes géographiques en couleur

Coloured ink (i.e. other than blue or black) /

Encre de couleur (i.e. autre que bleve ou noire)

Coloured plates and/or illustrations /

Planches evou illusirations en couleur

Bound with other material/

Relié avec d'autres documents

Only edition available I

Seule édition disponible

Tight binding may cause shadows or distortion along interior margin / La reliure serrée peut causer de l'ombre ou de la distorsion le long de la marge intérieure.

Blank leaves added during restorations may appear within the text. Whenever possible, these have been omitted from filming / II se peut que certaines pages blanches ajoutées lors d'une restauration apparaissent dans le texte, mais, lorsque cela était possible, ces pages n'ont pas élé tilmées.
L'Institur a microfilmé le meilleur exemplaire qu'il lui a été possible de se procurer. Les détails de cel exem. plaire qui sont peut-étre uniques du point de vue bibliographique, qui peuvent modifier une image reproduite, ou qul peuvent exiger une inodification dans la méthode normale de filmage sont indiqués ci-dessous.

Coloured pages / Pages de couleur

Pages damaged / Pages endommagées

Pages reslored and/or laminated /

Pages restaurées eVou pelliculées

Pages discoloured, stained or foxed /

Pages décolorées, lachelées ou piquées

Pages detached/Pages détachées

Showthrough / Transparence

Quality of print varies /

Qualité inégale de l'impression

Includes supplementary material I

Comprend du matériel supplémentaire

Pages wholly or partially obscured by errala slips, tissues, etc., have been refilmed to ensure the best possible image / Les pages tolalement ou partiellement obscurcies par un feuillet d'errata, une pelure, elc., ont été filmées à nouveau de façon à oblenir la meilleure image possible.

Opposing pages with varying colouration or discolourations are filmed twice to ensure the best possible image / Les pages s'opposant ayant des colorations variables ou des décolorations sont filmées deux lois afin d'obtenir la meilleure image. possible.
Additional comments /

Commentaires supplémentaires:
Copy has manuscript annotations.

Cette cople a des annotations manuscrites.

This itern is filmed at the reduction ratio checked below /

Ce document est filmé au raux de rèduclion indiqué ci-dessous.

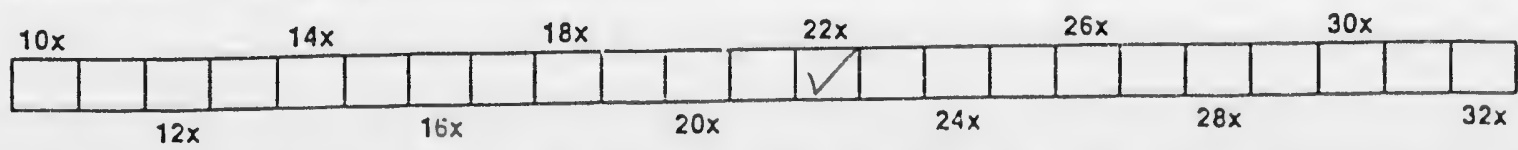


The copy filmed here has been reproduced thanks to the generosity of:

\section{Toronto Retierence Library}

The images appearing here are the best quality possible considering the condition and legibility of the original copy and in keeplng with the filmine contract specifications.

Original copies in printed peper covere are filmed beginning with the front cover and ending on the last page with a printed or illustrated impres. sion, or the beck cover when appropriate. All other original copies are filmed beginning on the first pege with a printed or lllustrated impreesion, and anding on the last pege with a printed or illustrated impression.

The last recordad freme on each microfiche shall contain the symbol $\longrightarrow$ Imeaning "CON. TINUED"), or the symbol $\nabla$ (meaning "END"). whichevar applies.

Maps, plates, charts, etc., may be filmed at different reduction ratios. Those too large to be entirely included in one exposure are filmed beginning in the upper left hand corner, left to right and top to bottom, as many frames as required. The following diagrams illustrate the method:
L'exemplaire filmó fut reproduit grâce a la goneroeite de:

Toronto Reference Library

Les images suivantes ont dto reproduites avec le plus grand soin. compte tenu de la condition ot de la nettete de l'exemplaire filmd, et on conformite avec les conditions du contrat de filmage.

Les exemplaires originaux dont la couverture en papier est imprimbe sont filmós en commencant par le premier plat et en terminant soit par la dernidre page qui comporte une empreinte d'imprassion ou d'illustration, soit par le second plat, selon le cas. Tous les autres exemplaires originaux sont filmes an commençant par la premidre page qui comporte une empreinte d'impression ou d'illustration et terminant par le dernidre page qui comporte une telle empreinte.

Un des symboles suivants apparaitra sur la dernidre image de chaque microfiche. selon le ces: le aymbole $\longrightarrow$ signifie "A SUIVRE". le symbole $\nabla$ signifie "FIN".

Les cartes, planches, tableaux, etc.. peuvent btre filmos a des taux de reduction différents. Loraque le document est trop grand pour âtre reproduit en un seul cliche. il est filme a partir de l'angle supbrieur gauche, de gauche a droite. ot de haut en bas, en prenant le nombre d'imeges ndcessaire. Les diagrammes suivants illustrent le methode.
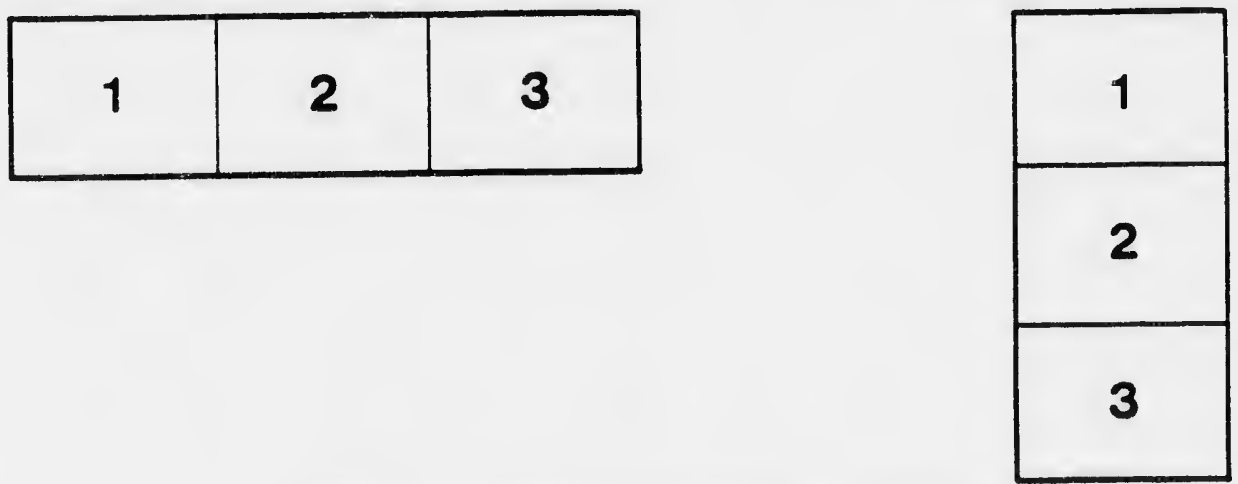

\begin{tabular}{|l|l|l|}
\hline 1 & 2 & 3 \\
\hline 4 & 5 & 6 \\
\hline
\end{tabular}




\section{MICROCOPY RESOLUTION TEST CHART}

(ANSI and ISO TEST CHART No. 2)
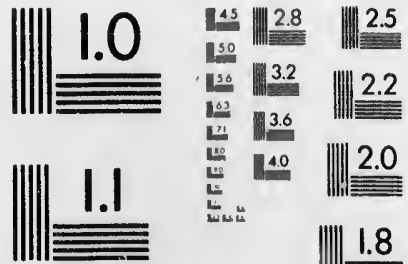

4u․ $4.0 \quad 2.0$

L

约么
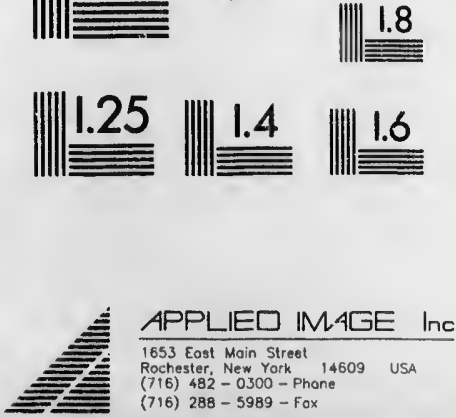


\title{
LIST OF BIRDS
}

onsERved IN THE

\section{VICIN ITY OF II AMILTON, C.W.}

\author{
ARRANGED $\triangle$ FTER THE SYSTEM OF $\Lambda U D U B O N$.
}

BY THOMAS MILWRAITII, ESQ.

From the Canadian Journal for ,Fely, 1860.

The olject of the writer in preparing the following list, has been to aflord sueh information as may be of use, should inquiry at any future perind he mule re. garding the birds frequenting this part of the country. In its present state, the list has been drawn uy from observations mala during ocensional exeursions within a period of four years. Those who are acquainted with the suljeet will see that it is necessarily ineomplete; but it will be easy th ald the narues of such species as may yet be found. In order that the list may be strictly locul, no species has been mentiened whieh has not been found within six miles of the eity limits.

Genus Buteo.-Buzzand.

1. B. borealis-Red-tailed Ilawk. Seen in spring and fall. Not very common.

2. B. linestus - Red-shouldered Hazok. More plentiful than the preceding, which it resembles in appearance and habits,

3. B. lagopus-Rough-legged Buzzard. Frequents the marslyy shores of the Bay; feeding on mice and wounled birds.

4. B. Pennsylvanicus-Broad-10inged Baczard. Abundant luring spring. Frequents the meadows near the Lake.

Genus Haliætus.-Sea Eagee.

1. H. leucocephalus-Bald Kagle. A fow pairs winter round the Bay Slote, feeding on musk-rats, gulls, \&e. The young birds ans of a uniform brown eolour; beiug more plentiful, and more easily approaehed than the adnit.

Genus Pandion.-Osprey - Fisir.Hawk.

1. P. Halisetus-Fish-Hawk. Seen fisbing in the Bay in spring and fall. Not known to brecil here.

Geuus Falco,-Falcon.

1. F. peregrinus-Peregrine Falcon. Accidental. Has been observed striking down ducks near Burlington Bench.

2. F. Folumbarius-Pigeon Hawk. Common in nutunn, when it attents the flocks of blackbirds which roost in the marsh. 


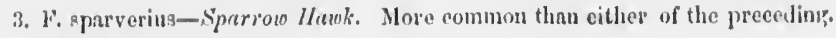
13reets nent the city.

Genus Astur,-IIATir.

1. A. Cooperi-Cooper's Iluwh. Seen in upring and fall, Not eommon.

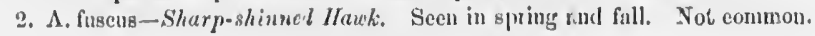

Genus Cirens.-Dlannari.

1. C. cyaneus-Common Ilarrier. Often seen sailing over the marshes; partieularly during the fall.

Genus Surnit.-Day OWL.

1. S. funeren-Mawk Owl. Ocensionally met with during severe winters,

3. S. nyeten-Snowy Oul. Very plentiful during sone winters, nt the bench. Between November, 1858. und Mareh, 1859 , seventeen specimens were brought to market by fishermen and others. Between November, 1859, and Mareł, 1860, only two inclividuals were killed.

Genus Ululi.-Nigntr Ow.

1. U. Aendien-Sent-1uhet Owl. Frequently enught during the day, in empty houses, thronghout the conntry. Not seen in winter.

Genus Symium,-Hootive OwL.

1. S. nebulosum-barred Owl. The most common species of this fumily. Been in spring and full: not observed in summer.

Genus Otus.-Eaned OWl.

1. O. vulgaris-Long-Eared Owl. Rather rare. Observed only in tho fall.

2. O. brachyotus-Short-Eared O1w?. SLore frequently secu than tho preeding. Observed to hunt during the day, in eloudy weather.

Genus Bubo.-Horned OwL.

1. B. Virginianus-Virginian IIorned Owl. Not very rare. No particular haunt.

2. 13. Asio-Mottled Horned Oul. One shot on tho top of a store-house at Cook's Whurf, Norember, 1859.

Genus Caprimulgus.-Goat Stcken.

1. C. vociferus-Whip-poor-Will. Geuerally distributed. Common. Genus Chordeiles,-Nigut Hawk.

1. C. Virgininus-Night IIawk. Abundaut. Breeds in the woods near the Bay . Genus Chaetura, - Šwire.

1. C. pelasgria-Chimncy Swallow. Abuudant everywhere.

Genus Hirundo.-Swallow.

1. I. purpuren-Purple Martin. Quite common in the eity.

2. 11. bieolor-White-bellied Swallow. Abundant. Generally distributed.

3. 11. fulva-Cliff" Stoallow. Less common than the preeeding. Builds in eolonies on the outside of barns, \&c.

4. H. rustien-Barn Swallow. Quite common. Builds inside of barns, fic.

5. H. riparia-Bank Swallow. Abundant. Nests in sand-bauks round the Bay Shore and elsewhere. Genus Musicapa--Flyeatcher.

1. M. tyranuus-Tyrant Fiycatêêr. Generally distributed. Not abuudant. 2. M. erenita-Great Cresicd Flycatcher. Quite common in the woods. 


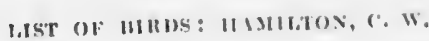

3. It. Cooperi-Cooper's Flycalcher. One indivilund ulunt in a swamp went the

Bay Shore.

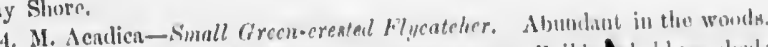

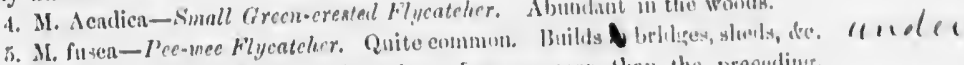

is. N. virens-Wood l'eewee Folycatcher. Less common than the preceding.

Frequents doat treos.

7. .1. rutieilla-Relstarl. Common in tho woods, in sumener.

8. M. fluviventris - Yellowo bellied Filyatelier. Only one finmi. (Not mentioned by Aulubon.)

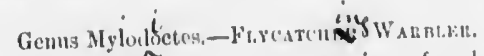

1. M. mitratus-Ilooded Wẩbler. Only one specinen fouml.

2. M. Canadensis-Canada Flycatcher. Quite common lluring spriug aut carly summer.

3. M. Wilsoni-Wilson's Flyculcher. Only nue specimen Lutul.

Geuus Sylvicola. -Wood Wandilis.

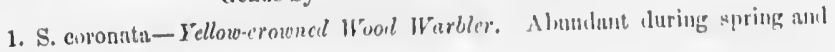
fall.

2. S. striata-Black-poll Wool Warbler, Rather rume. Arrives late and leaves early.

3. S. castunea-Baybreasled Wool Wierbler. A regular visitor in spring. Not numerous.

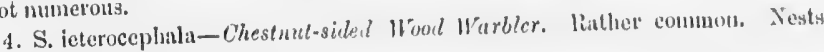
imoug the briat's.

5. S. vinus-Xine-crepping Wool Witrbler. Quite common. Oun of the firat to alrive.

6. S. Tarus-IIemlock Warbler. Observed in September only.

7. S. vircus-Black-lhroated Green Wool Warbler. Ruther common in sprim:

8. S. muritima-Cape Hay Wool Warbler. Rare. T'wo specimens proeurd.

9. S. corrulea-Carulean Wool Irarbler. Abundant in soine seasons: less su

in others.
10. S. Blackburnie-Blackburnian Wood Warbler. A regular visitor, in uncertain number's.

11. S. wativa-Yellow-poll Warbler. Abundant. Builds in shade trees in the city.

12. S. Petechia-Ycllow Red-poll Warbler. Common in the fall; rare in spring.

13. Americana-Blue. Yollow back Wood Warbler. Not very plentiful.

14. S. Canadensis-Blach-throatcl Blec 11 ood Warblcr. Plentiful in spriug.

15. S. maculosa-Black and Follow Woot Warbier. $\Lambda \mathrm{u}$ irregular spiring visitor.

Gemus Trichas.-Gizound Warhene.

1. 'T. Matulandica-Ilaryland Yellow-throat. Not common neu' the city: more 10 in retired swamps. p) 2. T. Plhilatelphila. Rire. One found May $2 s t h, 1860$. A Guus Molinaiil. - Swane Warncea.

1. II. celat:-Orange crotoned Steamp Warbler. Only one specimen found. 
2. 11. subrieapillat-Nashville Sioanp Warbler. Qulto common. Irecda ucar the city.

3. II. clirysoptern-Uolden.wingal Swamp Warbler. Ouly one sqecimen founcl.

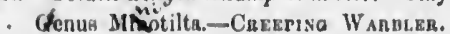

1. M. varia-Black and White Creeping Warbler. Abuulant in the woods, Genus Certhis,-Cueneru.

1. ('. Limiliarls-Broun Trec Creoper. Common. Resilent. Genus Troglodytes, - WaEN.

1. T, nelou-House Wren. A fow juirs speml the summer in the gardeus of the eity.

2. T. hy funalis - I'inter Wren. Conmou in sprlng nnd full.

3. T. pulustris-Marah Wren. Found in ull the marshes roum the lay in shummer.

Cienus Parus.-T'st.

1. P. ntrienpillus-Blach-eaphed 'T'it. Abundant. Resident.

Genus Regulus.-Ḱriserst.

1. R. satraya-Gold-crested Wren. Plentlful in spring and fall.

2. R. calouduln-Ruby-crowned Wren. Plentiful in s]ring aul fult. Cenus Slalin.-Biur: BıRD.

1. s. Wilsoni-Common Blue Bird. Plentiful from early spring till late in the fall.

Genus Orpheus.-Nocking Bird.

1. O. Carolinensis-Cat Bird. Quite common. Frequents low thickets.

2 O. Rufue-Brown Thrush. Less common than the preecding.

Genus Turdus.

1. T. migraturius-Rotin. Abundant; breeds in the eity gardens,

2. T. mustelinus-Wood T'hrush. Ruthor raro. Frequeuts oolitn'y wook,

3. 'T. Wilsoni-T'awny Thrush, Rather common.

4. T. solitarius-Hermit Thrush. Rather common. Similau in mauner and haunt to the preecding.

Genus Seiurus.-Woon Wagtalls.

1. S. nuroeapillus-Golden-erowned Wood Wagtail. Common in the rounds in summer.

2. S. novneboracensig-Aquatic Wood Wetglail. Common; less so than the preceding.

\section{Geuns Anthus.-Pirit.}

1. A. Ludovicinnus-American Pipit. Straggling floeks secn in spring und fall. Genus Aluuda.-Iank.

1. A. alpeetris-Shore Lark. Oecasionally seen il company with plectrophtues nivalis.

Genus Pleetrophanes,-Lank Bunting.

1. P. Lapponien-Lapland Lark Bunting. Ocensionally found in company with the eueceeding speeies.

2. P. nivalis-Snow-fake. Abundant while snow remaius on the ground. Genus Emberiza.-Buntıxg.

1. E. gramiuca-Bay-winged Bunting, Found in any grass field iu summer. 
2. 3. Savanna-Savanuah Bunting. Rather rare. Similar in labits to the preceding.

3. 1\% pusilln-Field Sparrono. Not very ummerous; breols near the city.

4. F, socialis-Chipping Sparrow. Quite esmmon. Builds in shude trees in strects.

5. F. Caualensis-Tree Spurrow. Suall floeks scen during winter.

6. E. pasecrinn-Yellow winged Bunting. lather ruro.

Genus Niphon-SNow Bho.

I. N. hyemalis-Common Snou Zirk. Conumon. Resident.

Genus Splza- - Paznted Buntisa.

1. S. eyanea-Indigo Bird. Common in the woods from May till september. (ienus Amnodramus, - Snone Fisen.

1. A. palustris-Swamp Sparrow. Breeds in tho reed beds of the Buy.

Gienus Linaia,-Tinset.

1. L. minol-Lesser liedyoll limuet. A winter visitor. Plentiful in soure вепнопв; If is so in others.

2. I „II - Pine Linnet. L.css numerous than tho preceling.

Gesus Carducilis.-Gots Fiscrs.

1. C. tristis-Gold Finch, Abundant. A few renain duriug winter.

Genus Fringilla.-Fincis.

1. F. Ilinen-jox-coloured sparrow. Aecidental in tho fall.

2. F. melodia-Song Sparrov, Abundant fron Mach till November.

3. 1. Pennsylvanics-White Throated Sparrow. Commson in spring and fall.

4. F. Icueophrys-IVhite-erowned Sparrow. Rather rare. Only seen in spring.

(ienus Pipilo.-Grousd Fixca.

1. I'. erytliropthalmus-'l'oske Bunting. Not very numerous.

Genus lisythrospiza.-Punpre Frixer.

1. E. purpurea-l'urple Finch, Oeensional in the woods in winter.

Genus Corythus. - l'ine Fisen.

1. C. enuclentor-Pine Grosbeak. A winter visitor, nppenring in consideraillo numbers in some seasons, aud not at ull in ot... - . Common during tho winter of $1859-60$.

$$
\text { Genu- Loxin,-Crussistle. }
$$

1. L. Curvirostra-Crossbill. An irregular winter visitor.

Genus Coceoborus,--Sone (irosb wak.

1. C. Ludovicianus-Lose-breasted Grosbak. Not very nunerous. Frequents secluded groves.

Genus Pyrtuga.-Reu Bind.

1. P. lubra-Searlet Tanager. Common in the woods in sumuer.

Genus Dolichonyx:-Ricr: Bund.

1. D. oryzivorn-Bob-o-link. Common. I'requents grass fields.

Genus Molothrus,-Cow Bıad.

1. M. pecoris-Common Cono Bird. Abundant all over the country.

Genus Agelaius,-Marsi Buákmrn.

1. A. phoeniceus-hed-roinged Starling. Abundant in ull the morshes. 
(icuss Icterus, - Ilavo vEsT.

1. I. Bultimore-Baltimore Oriole. Common in tho woods abul orchurils.

Genus (Quisenlus,-Cnow Blackвнu).

1. Q. versicolor-Croto IBlackbird. Seen ill spring and fall. Not obmerval to breal nenr the cily.

2. Q. lerrugineus-Kusty (irackle. Abundsent in the full, whica they apend the diny in the plonghed fichls, and ront in the reeds of tlo morsh at night.

(iemua Sturuella.-Mleadow Stamuivo.

S. Ludosichna-Alealou Lark. Cowmon from enty spring till lato in the fall.

Genus Corvus.-Chow.

1. C. Americanus-Conmon Crou. The main hody migratoly; a few resident. ínus Garrulus,-3AY.

1. Ci, eristatus - Blue Jay. Common. $\Lambda$ few resislent.

Genus Lanius.-Sнакк.

1. L. burenlis-American Shrike. A few individenls secu cvery wluter.

2. L. Luduvieinnus-Logyerheal Shrike, "Two individusls shot in April, 1800 . Not observed prior to that dnte.

Genua Vireu,

1. V. Hnvifrons-l'ellow-throated Virco. Not very numernus.

2. V. gilvus-Warbling Greenlet. Ruther common. Visits the shade trees in the eity.

3. V. olivncens-Red-eyed Greenlet. Cumnon in the woods in summer.

Geuus Bombycilli,-W W W W was.

1. B. gnriula-Bohemian Chatterer. An irregular winter vistor. Usunlly seen in company with the pine grosbenk.

2. B. Curolinensis-Cedir Bird. Quilo common during summer, frequently staying late in tho full.

$$
\text { Genus Silta.-Netuatch. }
$$

1. S. Curolineusis - Whita.bellied Nuthatch. Conmon. liesident.

2. S. Camadensis-Red.bellied Nuthateh. Common. Not seen in sumuser.

Genus Trochilus.-Humana Birv.

1. T. colubris - Ruby-throated IItmming Bircl. Conmon. Seen wherever there aro flowers in sunmer.

Genus Alcedo,-Kíng Fisher.

1. A. Alcyon-Belted Kingfisher. Common alorg the Bay shores.

Genus Picus, -Woodpecker.

1. P. villosus-Hairy Woodpecker. Quite common. Resident.

உ. P. pubesecns-Douny Woodpecler. Quite common. Resillent.

3. 1. varius-Ycllow-bellied Woodpeeker. Comunon during summer; breeds near the city.

-It is possible that this may provo to bo the Collyrio excu fuitmoides of Bairl, as aceording to lhat author, L. Ludoricionus is found only in the Mouth Atlantic and finle States: whisle $C$. c.xeufbitoroides las been grad?ally advanching from the west, and might be expected to ocenr here about this time. Without comparing specinens, it is diflieult to distinguish between the $t$ wo. 
HAT OF HIIDS: HAMUTUN, r. W.

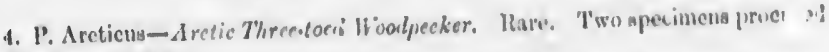
in Noventer, 1859.

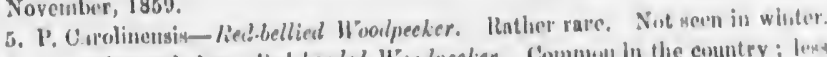

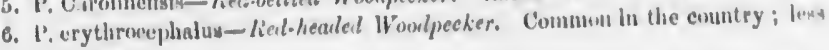
so near the eity.

7. 1'. auratus-Gold.mngel Woolpicker. Qnite cummon. Brepds near the eity. (ienus Coccyzhn, - Amatican Cucroo.

1. C. erythropthalinu-Bherk-billeil Guekvo. Not very raro.

ricuns betopistes,-Lown.'TAure Dovx.

1. J.migruturia-Passengor Pigcon. A rugular viaibur, in uncertain munbre

2. Is. Carolinensia-Cisolina Hove. Aecidental, in the bill

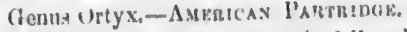

1. O. Virginiana-l'artrid!e Qnail. Common in foll and wintur'.

Geuns Tetrao,-Guouse.

1. 'T. umbellus--liugled tironse. Comnun. Resident. Genug Cialinuln,-G.1.1.r:vule.

1. G. chloropus-Common Cinlletule. Found in the numshes. Net very numerulus.

(ienus Fulien.-Coor.

1. I. American-Common Cool. Found in tho marshes. Fot plentiful,

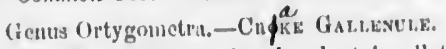

1. O. Curolinus--s Sora litil. Extremely abundant in n!l the nutroles fluring stimmel.

$$
\text { (tenus Rallus.-Ratl. }
$$

1. R. crepitans-Clupper Revil. Ocensional, in the marsh.

2. R. Virgininus - Virginian Rail. slore ples. iful than the preenling

3. R. ulegnns-G'reat Led-8reasted Rail. Acidental. One specimen funnil.

Getus Charadrius,-Plovrin.

1. C. II elvetions-Blacli-lielliel Plover. A regular visitor at the Beach in ppring and fall.

a. G. marnoratus-Golden Plover. More numerous than the preceding.

3. C. voeiforus-Kildeer Plover. Ocensional. Never numerous.

1. C. semipalmatus-Ring Plover. Numerons in spring and fill.

Genus strepsilıs.-Tursstuxe.

1. S. interpres-T'urnstone. Ocenstonal nt the beneh.

Genus 'Tringa.-Savoriper.

1. T. pectoralis-Pectoral Sandpiper. Abundant in the fall.

2. T. aljina-Red-baeked Sandpiper. Extremely alundant about the 25th of May.

3. T. snbarquata-Curlew Sandpiper. Occasioual. Not numerous.

4. T. himatopus-Long-leggel Sandpiper. $\Lambda$ fow seen at the bench every season.

5. 'T' semipanatn-Semipalnated Sandpiper. Very abundant in spri grgnd fall.

6. T. pusilln-Liltie Sundpiper. Not quite so uumerous as the preecding, with which it ass uiates. 
7. T. arenaria-Sanderling Sandpiper. Quite common at the beacly,
8. T. islandien-Red-hent Sandpiper. Never very numerous. brea 2

Genus Lobipes.-Lовегоoт.

1. L. hyperborcus-IIyperboreen Lobefoot. Oceasionally seen in small ponds near the bay.

Genus Totanus.-TAtLer.

1. T. macularius-Spotted Tutler. Breeds uear all the muddy erecks round the Bay.

2. T, flavipes-Yellow-shanks Tatler. Rather eommon during spring and fall.

3. 'T. roeiferis--Tell-tale Tatler. Less numerons than the preeeding.

Geuus Limosa,- Gonwrit.

1. L. fedon-Great Marbled Golwit. Ocensional, Not numerous.

2. L. Hudsonica-IIulsonian Godwit. Rather rare.

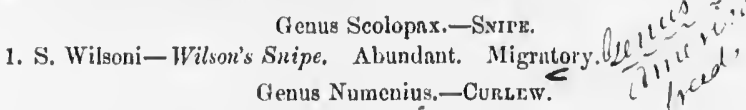

$$
\text { ate }
$$

g-billed Curlew." Aecidental on the Lake Shore.

S. Hudsonicus-Ifudsonian Curlero. Less frequent than the preeding. Genus Ardea.-Henos.

1. A. nycticorax-Black.crowned Night Heron, Aceidental. Migratory.

a. A. lentiginosa-Ameriean Bittern. Abundunt in all the marshes.

3. A. exilis-Least Bittern. Less nuuerous than the preceding.

4. A. Herodias-Great Blue Heron. Rather common.

Geuus Anser.-Goose.

1. A. Cauadensis-Canada Goose. A few rest on we Bay in their migratory course.

2. A. hyperboreus-Snow Goose. Accidental, in the Bay.

Genus Cygnus.-Swas.

1. C. Americauus-American Swan. Aecidental, in tlie Bay.

Genus Anas.-Duck.

1. A. boschas-Mallard. Common. Migratory.

2. A. obseura-Dusky Ditck. Comnıon. Migratory.

3. A. strepera-Gadwall. Rare, Only two individuals seen.

4. A. Americana-Widgeon. Numerous in spring and fall.

5. A. aeuta-Pin-tail Duck. Occasional, Not numerous.

6. A. spousa-Wood Duck. Quite common. A few breed near the marsh.

7. A. Carolinensis-Green-wingel Teal. Numerous in spring and fall.

8. A. discors-Blue-winged Teal. Less numerous than the preceding.

9. A. clypeati-Shoveller. Rather rare.

Genus Fuligula.-SEג DưcK.

1. F. valisneriann-Canuass-back Duck. Aceidental, Only two inclivicluals seen.

2. F. feriua-Red-head Duck, Rather common.

3. F. zoarila-Scaup Duck. Abundant in spring and fall. 
4. F. marila minor-Lrsaer Scaup lluck. Alumbunt. Sint distinguished by Autubon from the preceling.

5. F. rubida-kiuddy Duck. Inmense numbers taken with the gill-nets in some sensons; not seen in others.

6. F. fuses-Velet 1)ucli, Oecasional, in stomy weatluer.

7. F. elinurula-Crolien- Kiye luack. Not very mumerous.

8. F. albeola-bipper. Abundant in spring and fill.

9. F. glacinlis-Long tailed Duck: Abunlant. Winters in the Lalie. Atten caught in gill-nets along with white-tish, twelve tailes form slure, and at a depth of $200 f$ t. to 250 ft.

(ienus Mergu-, - kimcissks.

1. MI. mersanser-Goosmicr. Sut very plentiful.

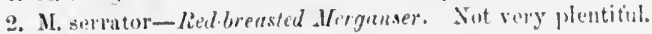

3. M. cucullatus-llooded Merganser. More mumeroms than eitleer of the preeceling.

$$
\text { Genu- Sternat-'Trex. }
$$

1. S hirmdo-Common Tirn. Visits the Bay ahment the end of May.

2. S. nigra-Black 7ern. Lsually necompanies receling.

(ienus Jarus. - Grot.

1. L. Bounpattii-Bonapurtes (iull. Common during fall.

2. L. argentatus-Ilerring Gull. Winters at the bencls

B. L. narius-Great Black backed Gull. Winters at the leadeh. Finy diflicult of appronch.

\section{Genus Uri.t-Gumbut.}

1. U. grylle-Black Giuillemot. Accirlentul, :Ifter easterly storms.

a. U. 'Troile-Fimlish cruillemot. Aecidentat, atter' storny wather.

Genus Colymbus - Drver.

1. C. gracialis-Loon, Often seen in the Buy.

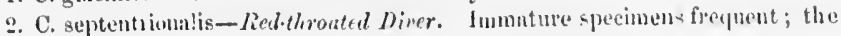
adult not observed.

(ienus Podiceps.-Giknk.

1. P', rubricallis-Red-necked Grebe. Rather rare. Sern only in sjring.

2. I'. cornutus- Horneed Girebe, Common during smminer.

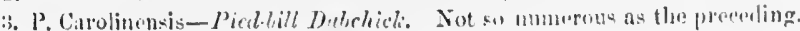


25

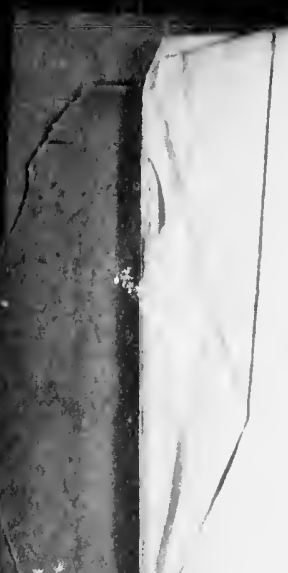




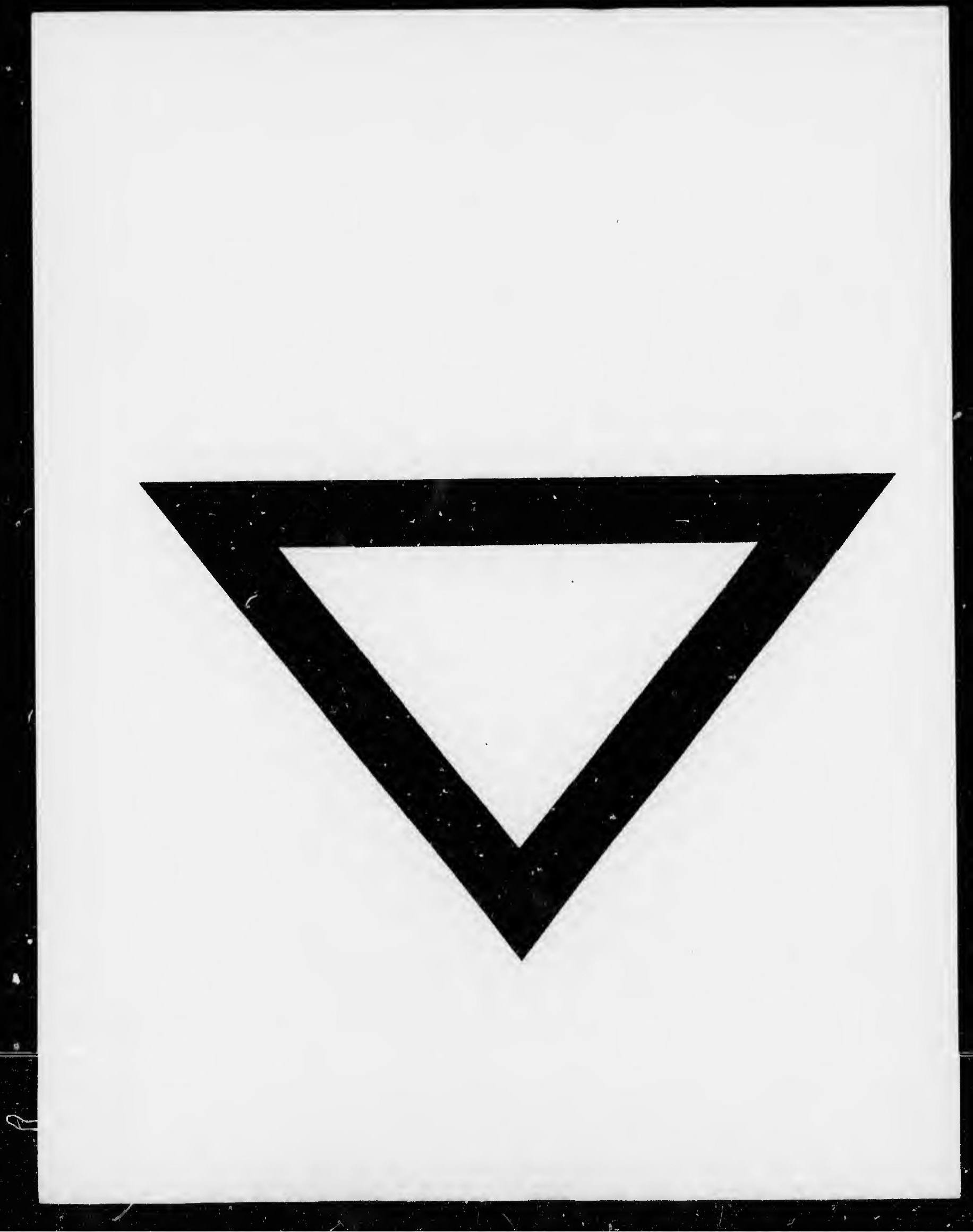

